\title{
HUBUNGAN KADAR LEUKOSIT TERHADAP KEJADIAN \\ KETUBAN PECAH DINI DI BLUD RUMAH SAKIT dr.DORIS SYLVANUS PALANGKA RAYA TAHUN 2018
}

\author{
The Relation Of Leukocyte Levels Toward The Incidence \\ of Premature Rupture Of Membrane In Cempaka Ward \\ BLUD Hospital dr. Doris Sylvanus Palangka Raya \\ Year 2018
}

\author{
Herlinadiyaningsih ${ }^{1}$, Dian Utami ${ }^{2}$ \\ Poltekkes Kemenkes Palangka Raya \\ (herlinadiyaningsih@ rocketmail.com)
}

\begin{abstract}
ABSTRAK
Latar Belakang : Ketuban Pecah Dini adalah salah satu komplikasi yang penting dalam Obstetri berkaitan dengan penyulit kelahiran serta komplikasi-komplikasi lain pada ibu dan janin. Terdapat peningkatan kejadian Ketuban Pecah Dini di Di BLUD Rumah Sakit dr. Doris Sylvanus selama 2 tahun terakhir sejak tahun 2016 hingga tahun 2017. Penyebab Ketuban Pecah Dini memiliki dimensi multifaktorial salah satunya adalah infeksi yang ditandai dengan adanya leukositosis. Penelitian ini bertujuan untuk menganalisis Hubungan Kadar Leukosit Terhadap Kejadian Ketuban Pecah Dini di Ruang Cempaka BLUD Rumah Sakit dr. Doris Sylvanus Palangka Raya .

Tujuan Penelitian : Penelitian ini bertujuan untuk menganalisa Hubungan Kadar Leukosit Terhadap Kejadian Ketuban Pecah Dini di Ruang Kebidanan BLUD Rumah Sakit dr. Doris Sylvanus Palangka Raya

Metode :Penelitian ini adalah penelitian kuantitatif dengan rancangan penelitian Observasional Analitik, yang menggunakan pendekatan Cross Sectional. Penelitian ini dilakukan di BLUD Rumah Sakit dr. Doris Sylvanus Palangka Raya dengan populasi sebanyak 407 orang ibu hamil dengan Ketuban Pecah Dini. Sampel dalam peneltian ini berjumlah 202 responden yang dipilih menggunakan teknik Purpossive Sampling.

Hasil : Berdasarkan tabel silang didapatkan 131 responden dengan kejadian KPD memiliki kadar Leukosit $\leq 12.000 / \mathrm{mm}^{3}$ dan 71 responden dengan kejadian Ketuban Pecah Dini memiliki kadar Leukosit $>12.000 / \mathrm{mm} 3$. Hasil analisis bivariat menggunakan Chi-Square diperoleh nilai p-value $=0,000$.

Kesimpulan : Ada hubungan antara kadar Leukosit dengan kejadian Ketuban Pecah Dini
\end{abstract}

Kata Kunci : Kadar Leukosit dan Ketuban Pecah Dini 


\begin{abstract}
Background: Premature Rupture of Membranes (PROM) is one of the most important complications in obstetrics related to birth complications as well as other complications for maternal and fetus. From 2016 to 2017, there is an increasing incidence of premature Rupture of Membrane in dr. Doris Sylvanus. The cause of premature rupture of membranes has a multifactorial dimension which is one of them is Infection that characterized by the presence of leukocytosis. This study aims to analyze the corelation of leukocyte levels toward the incidence of Premature Rupture of Membranes in Cempaka ward BLUD Hospital dr. Doris Sylvanus Palangka Raya.

Research purposes:This study aims to analyze the relationship of leukocyte levels to the occurrence of premature rupture of membranes in the BLUD Hospital Room Dr. Doris Sylvanus Palangka Raya

Method: This is a quantitative research with Observational Analytic research design, using Cross Sectional approach. This research was conducted at BLUD Hospital dr. Doris Sylvanus Palangka Raya with a population of 407 pregnant women with premature rupture of membranes. The sample in this research is 202 respondents selected using Purpossive Sampling technique

Result: Based on the cross table, there are 131 respondents with premature rupture of membrane incidence had leukocyte level of $\leq 12.000 / \mathrm{mm}^{3}$ and 71 respondents with premature rupture of membrane incidence had leukocyte level $>12.000 / \mathrm{mm}^{3}$. The result of bivariate analysis using Chi-Square obtained p-value $=0,000$.

Conclusion: There is a relation between leukocyte levels and incidence of Premature Rupture of Membranes
\end{abstract}

Keywords : Leukocyte Level and Premature Rupture of Membranes

\title{
PENDAHULUAN
}

Kehamilan adalah proses reproduksi biologis yang dialami oleh setiap wanita. Serangkaian fase akan dilewati secara berkesinambungan untuk menyempurnakan kehamilannya hingga saat persalinan tiba. Fertilisasi, implantasi, embriogenesis dan perkembangan plasenta merupakan rangkaian awal dari siklus kehamilan, termasuk pembentukan amniotic sac/ kantung yang berisi cairan ketuban (Norwitz,2008)

Salah satu fungsi ketuban adalah melindungi atau menjadi pembatas dunia luar dan ruangan dalam rahim sehingga mengurangi kemungkinan infeksi. Normalnya ketuban pecah saat memasuki persalinan. Namun ada kondisi dimana ketuban pecah sebelum waktunya. Ketuban Pecah Dini (KPD) adalah pecahnya ketuban sebelum inpartu, yaitu bila pembukaan pada primi kurang dari $3 \mathrm{~cm}$ dan pada multipara kurang dari $5 \mathrm{~cm}$. Ketuban Pecah Dini adalah pecahnya selaput ketuban sebelum proses persalinan dimulai (Pranoto, 2012)

Ketuban Pecah Dini merupakan komplikasi yang penting dalam Obstetri berkaitan dengan penyulit kelahiran, serta komplikasi-komplikasi lain pada ibu 
dan janin. Ketuban Pecah Dini dapat menyebabkan prematuritas, prolaps funiculli, hipoksia dan asfiksia, morbiditas dan mortalitas pada janin, sementara pada ibu dapat terjadi infeksi intra natal, infeksi puerperalis, partus lama, perdarahan post patum, meningkatkan tindakan opertif obstetricserta morbiditasdan mortalitas maternal.(Feryanto,2011)

Angka Kematian Ibu (AKI) di Indonesia masih cukup tinggi ketimbang negara-negara lain di kawasan ASEAN. Berdasarkan Survei Penduduk Antar Sensus (SUPAS) tahun 2015, AKI di Indonesia berada pada angka 305/100.000 kelahiran hidup.(Profil kesehatan 2015)

Penyebab ketuban pecah dini memiliki dimensi multifactorial, salah satunya adalah Infeksi. Terjadinya proses biomekanik pada selaput ketuban dalam bentuk proteolitik sebagai akibat adanya infeksi dapat memudahkan Ketuban pecah. Sehingga infeksi, merupakan penyebab penting kematian dan kesakitan ibu (Saifudin 2008)

AKI Kalimantan Tengah masih mengikuti angka nasional yaitu hasil Survei Demografi Kesehatan Indonesia (SDKI), jumlah kasus kematian ibu yang dilaporkan di Provinsi Kalimantan Tengah pada Tahun 2015 sebanyak 80 kasus. Adapun rincian penyebab langsung kematian ibu di Provinsi Kalimantan Tengah tahun 2015 sebagai berikut: 44 kasus (55\%) Perdarahan, Lain-lain 12 kasus (15\%), Gangguan Sistem Peredaran Darah (Jantung,Stroke) 10 kasus (13\%), Hipertensi Dalam Kehamilan 9 kasus (13\%), Infeksi 4 kasus (5 \%) dan Gangguan Metabolik 1 kasus (1\%), dimana perdarahan dan infeksi termasuk dalam komplikasi yang disebabkan oleh Ketuban Pecah Dini.(Profil kesehatan 2015)

Wanita hamil sangat sensitif terhadap berbagai mikroorganisme yang dapat menyebabkan infeksi, yang kemungkinan diakibatkan oleh toleransi imunitas maternal terhadap fetal. Deteksi dini terhadap adanya infeksi perlu dilakukan untuk mencegah terjadinya Ketuban Pecah Dini serta komplikasi lain pada kehamilan dan persalinan.

Berdasarkan beberapa teori yang telah dikemukakan, kejadian Ketuban Pecah Dini dapat disebabkan oleh infeksi yang ditandai dengan adanya leukositosis. Leukositosis dapat dinilai melalui pemeriksaan darah yang digunakan sebagai salah satu upaya dalam memonitoring kemungkinan terjadinya infeksi pada kehamilan ibu(Rahayu 2018)

Berdasarkan data laporan ruang Kebidanan yang berhasil dihimpun di BLUD Rumah Sakit dr. Doris Sylvanus Palangka Raya, jumlah kejadian Ketuban Pecah Dini pada tahun 2016 yaitu sebanyak 330 kasus. Sedangkan pada tahun 2017 terjadi sebanyak 407 kasus.

Berdasarkan uraian di atas, maka peneliti tertarik untuk melakukan penelitian tentang Hubungan Kadar Leukosit Terhadap Kejadian Ketuban Pecah Dini di Ruang Kebidanan BLUD Rumah Sakit dr. Doris Sylvanus Palangka Raya.

\section{METODOLOGI PENELITIAN}

Penelitian ini adalah penelitian Kuantitatif dengan rancangan penelitian Observasional Analitik, yang menggunakan pendekatan Cross Sectional. Populasi dalam penelitian ini adalah semua ibu hamil dengan Ketuban Pecah Dini yang 
dirawat di ruang kebidanan BLUD Rumah Sakit dr. Doris Sylvanus Palangka Raya sejak tanggal 1 Januari hingga 31 Desember tahun 2017 sebanyak 407 orang. Alat yang digunakan untuk mengumpulkan data pada penelitian ini adalah format pengumpulan data dan rekam medik responden, yaitu berupa daftar isian untuk mencatat data dari rekam medik BLUD Rumah Sakit dr.Doris Sylvanus Palangka Raya berdasarkan kriteria inklusi dan kriteria eksklusi yang telah ditetapkan.

Teknik pengolahan data dalam penelitian ini adalah: Editing, Coding, Data Entry, Cleaning Data dan Tabulatin. Pada penelitian ini dilakukan uji analisis menggunakan Chi-Square dengan menggunakan SPSS versi 20.

\section{HASIL DAN PEMBAHASAN}

Tabel 1 Distribusi frekuensi berdasarkan kejadian Ketuban Pecah Dini

\begin{tabular}{lcc}
\hline $\begin{array}{l}\text { Kejadian Ketuban } \\
\text { Pecah Dini }\end{array}$ & Frekuensi & Persentase (\%) \\
\hline $\begin{array}{l}\text { Ketuban Pecah Dini } \\
\text { Aterm }\end{array}$ & 174 & 86,1 \\
$\quad \begin{array}{l}\text { Ketuban Pecah } \\
\text { Dini Preterm }\end{array}$ & 28 & 13,9 \\
\hline \multicolumn{1}{c}{ Total } & 202 & 100,0 \\
\hline
\end{tabular}

Berdasarkan tabel, dapat diketahui bahwa dari 202 responden yang masuk ruang Cempaka BLUD Rumah Sakit dr. Doris Sylvanus Palangka Raya sebagian besar mengalami Ketuban Pecah Dini Aterm (UK 37-42 minggu) yaitu sejumlah 174 orang $(86,1 \%)$, dan sejumlah 28 orang $(13,9 \%)$ mengalami Ketuban Pecah Dini Preterm (UK < 37 minggu).

Tabel 2 Distribusi frekuensi berdasarkan Kadar Leukosit responden

\begin{tabular}{ccc}
\hline Kadar Leukosit & Frekuensi & Persentase \\
\hline$\leq 12.000 / \mathrm{mm}^{3}$ & 131 & 64,9 \\
$>12.000 / \mathrm{mm}^{3}$ & 71 & 35,1 \\
\hline Total & 202 & 100,0
\end{tabular}

Berdasarkan tabel dapat diketahui bahwa dari 202 responden yang masuk ruang Cempaka BLUD Rumah Sakit dr. Doris Sylvanus Palangka Raya dengan Kejadian Ketuban Pecah Dini yang memiliki kadar Leukosit $\leq 12.000 / \mathrm{mm}^{3}$ lebih besar jumlahnya dibanding responden yang memiliki kadar Leukosit $>12.000 / \mathrm{mm}^{3}$, yakni sebanyak 131 orang $(64,9 \%)$ dan 71 orang $(35,1 \%)$, berturut-turut. 
Avicenna Journal of Health Research. Vol 1 No 2. Oktober 2018 (27 - 37)

Tabel 3 Distribusi responden berdasarkan hubungan Kadar Leukosit terhadap Ketuban Pecah Dini

\begin{tabular}{lrlrllllc}
\hline $\begin{array}{l}\text { Kadar } \\
\text { Leukosit }\end{array}$ & \multicolumn{3}{c}{ Ketuban Pecah Dini } & Total & OR & $\begin{array}{c}\text { p- } \\
\text { value }\end{array}$ \\
\cline { 2 - 5 } & \multicolumn{1}{c}{ Aterm } & \multicolumn{1}{c}{ Preterm } & & & & 0,000 \\
$\leq 12.000 / \mathrm{mm}^{3}$ & $\mathbf{N}$ & $\mathbf{\%}$ & $\mathbf{N}$ & $\mathbf{\%}$ & $\mathbf{N}$ & $\mathbf{\%}$ & \\
$>12.000 / \mathrm{mm}^{3}$ & 49 & 95,4 & 6 & 4,6 & 131 & 100 & & \\
$\quad$ Jumlah & 174 & 86,1 & 22 & 31 & 71 & 100 & & \\
\hline
\end{tabular}

Berdasarkan tabel diilustrasikan mengenai proporsi antara Kadar Leukosit dengan kejadian Ketuban Pecah Dini, diperoleh sejumlah 131 responden dengan kategori kadar leukosit $\leq 12.000 / \mathrm{mm}^{3}$ dimana sebanyak 125 responden $(95,4 \%)$ mengalami Ketuban Pecah Dini Aterm dan 6 responden (4,6\%) mengalami Ketuban Pecah Dini Preterm. Sementara pada kategori kadar leukosit > $12.000 / \mathrm{mm}^{3}$ terdapat 49 responden $(69 \%)$ yang mengalami Ketuban Pecah Dini Aterm, dan 22 responden (31\%) yang mengalami Ketuban Pecah Dini Preterm dari total 71 responden.

Berdasarkan uji Chi Square mengenai Hubungan Kadar Leukosit terhadap kejadian Ketuban Pecah Dini di ruang Cempaka BLUD Rumah Sakit dr. Doris Sylvanus Palangka Raya didapatkan p-value 0,000, dimana $0,000<\alpha=0,05$, maka $\mathrm{H}_{0}$ ditolak dan dapat disimpulkan bahwa ada hubungan yang signifikan antara Kadar Leukosit dengan kejadian Ketuban Pecah Dini di ruang Cempaka BLUD Rumah Sakit dr. Doris Sylvanus Palangka Raya.

Berdasarkan hasil penelitian, ditemukan sebanyak 174 responden ( 86,1\%) yang mengalami Ketuban Pecah Dini di usia kehamilan aterm atau berada di usia kehamilan antara 37 hingga 42 minggu. Ketuban pecah dini aterm ini terjadi pada sekitar $10 \%$ kehamilan. Ketuban pecah dini merupakan salah satu dilema terapeutik terpenting dalam praktik obstetri saat ini, yang menyulitkan sekitar 5\% hingga $10 \%$ pada kehamilan hingga 30\% dari persalinan prematur(Jazayeri, 2017)

Hasil penelitian ini sesuai dengan teori, bahwa selaput ketuban sangat kuat pada kehamilan muda dan melemah pada trimester ketiga. Salah satu penyebab melemahnya selaput ketuban pada trimester terakhir adalah terjadinya perubahan biokimia pada selaput ketuban. Terdapat keseimbangan antara antara sintesis dan degradasi ekstraseluler matriks. Perubahan struktur, jumlah sel, dan katabolisme kolagen menyebabkan aktivitas kolagen berubah. Perubahan yang terjadi pada kolagen dapat disebabkan oleh berkurangnya tembaga dan asam askorbik (komponen kolagen) sehingga struktur kolagen bertumbuh abnormal (Prawirohardjo, 2010)

Degradasi kolagen dimediasi oleh matriks metaloproteinase (MMP) yang dihambat oleh inhibitor jaringan spesifik dan inhibitor protease, sehingga keutuhan selaput ketuban terjaga. Namun menjelang waktu persalinan, keseimbangan antara MMP dan TIMP mengarah pada degradasi proteolitik dari matriks ekstraseluler dan membran janin. Ketidakseimbangan antara MMP dan TIMP juga dapat menyebabkan selaput ketuban pecah karena terjadinya degradasi matriks ekstraseluler selaput membran ketuban (Kusuma , 2013) 
Selain itu, kekuatan selaput ketuban yang menurun memiliki hubungan dengan pembesaran uterus, kontraksi rahim dan gerakan janin yang umum terjadi pada kehamilan trimester ketiga. Ketuban pecah dalam persalinan secara umum disebabkan oleh kontraksi uterus dan peregangan berulang. Selaput ketuban pecah karena pada daerah tertentu terjadi perubahan biokimia yang menyebabkan selaput ketuban inferior rapuh.(Nugroho, 2010)

Pada penelitian ini, sebanyak 28 responden $(13,9 \%)$ mengalami Ketuban Pecah Dini sebelum umur kehamilan 37 minggu, dan disebut ketuban pecah dini preterm / preterm premature rupture of the membrane (PPROM). Ketuban pecah dini preterm terjadi pada sekitar 1 persen dari semua kehamilan dan berhubungan dengan 30 hingga 40 persen kelahiran prematur. Dengan demikian, memimpin penyebab kelahiran prematur yang teridentifikasi (setelah kurang dari 37 kehamilan minggu selesai) dan komplikasi, termasuk sindrom gangguan pernapasan, infeksi neonatal, dan intraventrikular pendarahan(Norwitzt, 2008)

Hasil penelitian ini serupa dengan yang dilakukan oleh Agatha Maria dan Utin Siti Candra Sari yang menunjukan bahwa jumlah responden yang mengalami Ketuban Pecah Dini pada usia kehamilan aterm ( $\geq 37$ minggu) lebih banyak dibandingkan yang dialami kelompok usia kehamilan Preterm dan Posterm, yakni masing-masing 44 responden dan 3 responden dengan p-value $=0,000(<0,05)$. Hasil penelitian ini juga didukung oleh penelitian yang dilakukan oleh Budi Rahayu dan Ayu Novita Sari, yakni sebanyak 80,3\% responden mengalami Ketuban Pecah Dini pada usia kehamilan aterm ( $\geq 37$ minggu) (Rahayu, 2017)

Penatalaksanaan yang dilakukan pada Ketuban Pecah Dini adalah bergantung pada usia kehamilan, apakah dialami di usia aterm atau dialami diusia preterm. Terdapat dua jenis penatalaksanaan yaitu penatalaksanaan aktif dan penatalkasanaan konservatif. Pada kehamilan aterm, pentalaksanaan aktif dilakukan untuk mengupayakan terminasi kehamilan dengan mempertimbangkan kondisi maternal dan kesejahteraan janin. Perlu dilakukan analisa lebih lanjut untuk memperkirakan adanya kemungkinan komplikasi pada keduanya. Analisa dapat dilakukan dengan memastikan ada tidaknya tanda-tanda infeksi maternal maupun fetal, kematangan paru janin, serta ada tidaknya tanda-tanda persalinan. Namun, pada penatalaksanaan KPD ini dapat dipengaruhi oleh faktor lain seperti keinginan dan harapan pasien. Hal tersebut dibuktikan pada penelitian yang dilakukan oleh George,dimana mayoritas pasien KPD dengan persalinan pervaginam memiliki intervensi obstetrik Bidan sebagai penyedia layanan kesehatan selain melaksanakan fungsi medis dapat melakukan pendekatan secara psikologis, dengan melakukan konseling pada pasien. Konseling dapat dilakukan dengan menerangkan pada pasien mengenai kondisinya saat ini serta prognosisnya mendatang. Kemudian pasien dan bidan dapat berdiskusi bersamasama mengenai manajemen yang akan dilakukan selanjutnya. Pada saat itu, bidan dapat merekomendasikan penatalaksanaan terbaik yang tentu saja sesuai dengan protap pelayanan, namun dengan lebih memperhatikan kondisi psikis dan memenuhi hak pasien untuk menetapkan keputusan. Hasil yang diharapkan selain terwujudnya keselamatan dan risiko minimal pada ibu dan janin adalah meningkatkan pemberdayaan diri pasien dalam kesehatan. .(Khumaira, 2012) 
Berdasarkan hasil penelitian yang telah dilakukan, dijumpai 131 responden $(64,9 \%)$ memiliki kadar Leukosit $\leq 12.000 / \mathrm{mm}^{3}$ dan sebanyak 71 responden $(35,1 \%)$ memiliki kadar Leukosit $>12.000 / \mathrm{mm}^{3}$.Leukosit atau Sel Darah Putih merupakan salah satu elemen pembentuk darah, yang membantu mempertahankan tubuh melawan invasi patogen menyingkirkan toksin, limbah dan sel-sel abnormal maupun sel-sel yang rusak. Tiap mikroliter dalam darah manusia tersusun atas 5000 hingga 10.000 sel darah putih. Pada wanita hamil, setiap bagian tubuh akan mengalami perubahan sebagai bentuk adaptasi terhadap adanya janin. Leukosit sebagai salah satu komponen darah yang penting, akan mengalami penekanan jumlah di trimester pertama dan kedua serta mengalami peningkatan di trimester ketiga. Hal tersebut merupakan perwujudan dari salah satu perubahan fisiologis di kehamilan. Meskipun cukup bervariasi selama kehamilan, hitung Leukosit biasanya berkisar dari 5.000 sampai $12.000 / \mu \mathrm{L}$. Selama persalinan dan masa nifas dini, jumlah dapat sangat meningkat mencapai $25.000 / \mu \mathrm{L}$ atau bahkan lebih namun reratanya adalah 14.000 sampai $16.000 / \mu \mathrm{L}$ (Martini, 2009)

Berdasarkan uji Chi Square didapatkan p-value 0,000, dimana 0,000 $<\alpha=0,05$, maka $\mathrm{H}_{0}$ ditolak dan dapat disimpulkan bahwa ada hubungan yang signifikan antara Kadar Leukosit dengan kejadian Ketuban Pecah Dini di ruang Cempaka BLUD Rumah Sakit dr. Doris Sylvanus Palangka Raya. Hasil penelitian menunjukan bahwa dari 202 rekam medik, secara berturut-turut terdapat 174 dan 71 rekam medik responden yang mengalami KPD di usia kehamilan aterm dan memiliki kadar leukosit melebihi normal yaitu $>12.000 / \mathrm{mm}^{3}$. Penelitian yang telah dilakukan oleh Iqsyadina Fikriya memiliki hasil yang serupa, dimana ibu hamil yang mengalami KPD memiliki hitung Leukosit yang lebih tinggi dibanding ibu hamil yang tidak mengalami KPD(Cuningham, 2013)

Seperti yang telah dipaparkan sebelumnya, bahwa terdapat batasan batasan nilai leukosit pada wanita hamil ialah mulai dari 5.000/mm3 hingga $12.000 / \mathrm{mm}^{3}$. Hal ini mengindikasikan apabila seorang wanita hamil memiliki hitung nilai leukosit $>12.000 / \mathrm{mm}^{3}$ dapat dikatakan ia telah mengalami leukositosis. Penyebab leukositosis pada wanita hamil antara lain infeksi virus, infeksi bakteri, dan infeksi protozoa.Infeksi merupakan salah satu faktor predisposisi KPD yang menyebabkan terjadinya biomekanik pada selaput ketuban dalam bentuk preteolitik sel sehingga memudahkan ketuban pecah (Amnionitis/Korioamnionitis). Penelitian terbaru yang oleh Jumrani mengemukakan bahwa ada peningkatan kadar leukosit pada wanita yang mengalami KPD, dan rerata nilai leukosit ini lebih tinggi dibanding wanita yang mengalami partus lama (Jumriani 2018)

Meskipun kenaikan kadar leukosit dapat menggambarkan adanya suatu mekanisme infeksi dalam tubuh, penegakan diagnosa infeksi tetap memerlukan beberapa pemeriksaan lain sebagai bahan pertimbangan. Penelitian yang dilakukan oleh Sonya S, dkk, menyimpulkan bahwa pemeriksaan leukosit kurang akurat sebagai indikator adanya infeksi dan inflamasi, akan tetapi dapat menguatkan diagnosa terhadap terjadinya infeksi dan inflamasi.Adanya perubahan vaskular dan rekrutmen menentukan tiga dari lima tanda lokal klasik inflamasi akut yaitu panas (kalor), merah (rubor), dan pembengkakan (tumor). Dua 
tambahannya yaitu nyeri (dolor) dan hilangnya fungsi (functio lesa) diakibatkan perluasan mediator dan kerusakan yang diperantarai leukosit(Sonya 2010)

Sehingga, untuk menegakkan diagnosa infeksi/inflamasi pada ibu hamil, dibutuhkan pemeriksaan tambahan selain bukti peningkatan jumlah Leukosit (sel darah putih) $>12.000 / \mathrm{mm}^{3}$. Adanya demam (dan takikardi), uterine tendernes, cairan amnion yang keruh dan berbau, serta kultur urine dapat mendukung hasil hitung leukosit dalam penentuan diagnosa. Pada penelitian ini, variabel terbatas pada kejadian KPD dan pemeriksaan kadar leukosit sehingga tidak dilakukan analisa mendalam mengenai faktor-faktor serta pemeriksaan lain yang dapat mendukung infeksi sebagai faktor penyebab.Teori lain menyebutkan bahwa batasan kadar leukosit pada wanita hamil adalah $15.000 / \mathrm{mm}^{3}$. Hal ini memiliki arti bahwa, faktor pencetus tingginya kadar leukosit pada sampel penelitian penelitian ini kemungkinan disebabkan oleh faktor selain infeksi(Ross, 2010)

Sebagian besar sampel penelitian $(86,1 \%)$ merupakan responden dengan usia kehamilan aterm yang mengalami kejadian KPD di usia kehamilan 37-42 minggu. Berdasarkan teori yang telah dipaparkan sebelumnya, diusia kehamilan ini mekanisme pecahnya selaput ketuban dipengaruhi oleh keseimbangan biokimia yang terganggu pada trimester akhir dan didukung adanya faktor pembesaran uterus, kontraksi rahim serta gerakan janin. Pada wanita hamil terutama di usia kehamilan aterm inipun mengalami perubahan hematologi sebagai proses adaptasi dengan kondisi tubuh hamil saat itu.Secara fisiologis, elemen-elemen pembentuk leukosit akan mengalami penurunan selama trimester pertama dan kedua yang kemudian akan meningkat kuantitasnya secara mencolok selama trimester ketiga.Penyebab peningkatan ini belum diketahui, tetapi hal yang sama dijumpai selama dan setelah kerja berat. Peningkatan ini mungkin mencerminkan kemunculan kembali Leukosit-leukosit yang semula tidak berada dalam sikulasi aktif. Peningkatan jumlah sel imun juga ditemukan di dinding uterus selama kehamilan normal. Sel-sel ini, terutama sel mast kemungkinan memiliki peran penting dalam memperantai kontraktilitas uterus (Nugroho ,2012)

Berdasarkan hasil penelitian, terdapat sebagian sampel yang mengalami KPD di usia kehamilan preterm dengan kadar leukosit yang lebih tinggi dengan sampel yang mengalami KPD di usia kehamilan aterm. Teori lain menyatakan, Ketuban Pecah Dini pada kehamilan preterm disebabkan oleh adanya faktorfaktor eksternal seperti infeksi yang menjalar dari vagina, ada polihidrmanion, inkompeten serviks dan solusio plasenta. Pernyataan yang serupa dijabarkan oleh jurnal kesehatan Denver Health (2018), dimana beberapa faktor berikut dapat meningkatkan resiko terjadinya Ketuban Pecah Dini pada usia kehamilan preterm yaitu adanya infeksi kantung amnion, infeksi lain (Klamidia, Vaginosis Bakterial), perdarahan selama trimester kedua dan ketiga, penyakit paru-paru, defisit nutrisi, BMI yang rendah, riwayat merokok selama kehamilan, hingga keadaan sosioekonomi yang rendah(Prawirohardjo, 2010)

Hasil Penelitian yang menunjukan bahwa faktor terbesar yang menyebabkan terjadinya Ketuban Pecah Dini adalah faktor infeksi sebanyak $18,96 \%$. Infeksi merangsang produksi prostaglandin, dimana dapat meningkatkan resiko pecahnya selaput ketuban preterm yang diakibatkan oleh degradasi dari selaput ketuban membran ketuban. Beberapa bakteri vaginal menghasilkan 
Phospolipase A2, dimana Phospolipase A2 ini akan melepaskan asam arakidonat. Lebih lanjut, respon imun tubuh terhadap infeksi bakteri akan meningkatkan produksi sitokin yang akan meningkatkan produksi dari Prostaglandin. Rangsangan terhadap sitokin juga berhubungan dengan induksi dari siklooksigenase II, yaitu suatu enzim yang akan merubah asam arakidonat menjadi prostaglandin. Dimana sitokin ini juga akan meningkatkan kadar MMP dan TIMPs menjadi tidak seimbang sehingga dapat menyebabkan melemahnya dan degradasi dari membran ketuban, pada akhirnya dapat mengakibatkan pecahnya selaput ketuban Meskipun hasil penelitian belum dapat menunjukkan adanya hubungan antara kadar leukosit dengan faktor infeksi, namun pemeriksaan darah yang dilakukan setiap menerima pasien yang masuk rumah sakit merupakan salah satu upaya dalam melengkapi penegakan diagnosa yang juga dapat dijadikan acuan dalam menentukan penanganan selanjutnya. Pemeriksaan laboratorium yang termasuk didalamnya perhitungan kadar leukosit dapat digunakan sebagai tolak ukur untuk memantau perkembangan penyakit, mencegah, atau meminimalisir terjadinya komplikasi lanjutan (Alim , 2016)

\section{SIMPULAN DAN SARAN}

\section{Simpulan}

Berdasarkan penelitian yang telah dilakukan dan hasil yang telah didapat, dapat peneliti simpulkan bahwa mayoritas Ketuban Pecah Dini dialami diusia kehamilan Aterm (UK 37-42 minggu) yaitu sejumlah 176 orang (87,1\%), dan sebanyak 28 responden $(13,9 \%)$ mengalami Ketuban Pecah Dini di usia Kehamilan Preterm (> 37 minggu), sertajumlah sampel yang mengalami Ketuban Pecah Dini memiliki memiliki kadar Leukosit $>12.000 / \mathrm{mm}^{3}$ sebanyak 71 sampel $(35,1 \%)$. Berdasarkan hasil analisis yang telah dilakukan, dapat dinyatakan bahwa ada hubungan antara kadar Leukosit terhadap kejadian Ketuban Pecah Dini $(\mathrm{p}$-value $=0,000)$

\section{Saran}

Bagi Institusi Rumah Sakit diharapkan penelitian ini dapat digunakan sebagai referensi untuk meningkatkan kualitas pelayanan Rumah Sakit terutama kualitas asuhan kebidanan pada berbagai kasus Obstetri dan Ginekologi, sehingga, dalam hal pelaksanaan asuhan kebidanan senantiasa dilakukan secara komprehensif

Bagi Profesi/Tenaga Kesehatan Rumah Sakit diharapkan penelitian ini dapat digunakan sebagai bahan referensi bagi tenaga kesehatan di Rumah Sakit, khususnya bagi bidan agar senantiasa melakukan analisa secara mendalam mengenai berbagai hasil pemeriksaan pada pasien. Sehingga dapat diketahui penyebab suatu kejadian dan mengantisipasi adanya kemungkinan komplikasi, khususnya pada ibu yang mengalami kejadian Ketuban Pecah Dini. 


\section{DAFTAR PUSTAKA}

Alim, Z, \& Safitri, Y, A, 2016, Faktor Yang Mempengaruhi Kejadian Ketuban Pecah Dini Pada Ibu Hamil Trimester III Di Rumah Sakit Bantuan Lawang, Jurnal Hesti Wira Sakti, Vol. 4, No. 1, 101-109 [28 Juni 2018]

Chandra, S. et al, 2012, Physiological Changes in Hematological Parameter During Pregnancy, Indian J Hematol Blood Transfus, July 15

Cunningham, F. G. et al, 2013, Obstetri Williams Volume, EGC, Jakarta

Dewita, M, Defrin, Rasyid, R, 2014, Perbandingan Antara Kadar Vitamin C Plasma Darah Hamil Aterm Pada Ketuban Pecah Dini Dengan Hamil Aterm Tanpa Ketuban Pecah Dini, Obgin Emas Vol.2 No.16, dari http://scholar.unand.ac.id/10933/ [26 Mei 2018]

Eleje, G, et al, 2010, Pre-Labour Rupture of Membranes at Term: A Review of Management in a Health Care Institution, AFRIMEDIC Journal, Vol.1, No.2 Juli-Desember, dari: www.afrimedicjournal.com/index.php/journal/article/[15 Mei 2018]

Feryanto, A, 2011, Asuhan Kebidanan Patologis, Salemba Medika, Jakarta

Fikriya, I, 2016, Hitung Leukosit Pada Ketuban Pecah Dini Sebagai Indikator Inflamasi Di Rumah Sakit Universitas Airlangga Tahun 2015, dari: http://repository.unair.ac.id/54702/ [26 Mei 2018]

Gant, N. F \& Cunningham, F. G, 2011, Dasar-Dasar Ginekologi, EGC, Jakarta Green, J. H, 2011, Fisiologi Kedokteran, Binarupa Aksara, Tangerang Hackenhaara, A. A., Albernaza, E. P., Fonseca, T. M., 2014, Preterm Premature Rupture Of The Fetal Membranes: Associationwith Sociodemographic Factors And Maternal Genitourinary Infections, J Pediatr (Rio J). 90:197--202 [10 Desember 2017]

Hidayat, A. A, 2014, Metode Penelitian Kebidanan dan Analisis Data, Salemba Medika, Jakarta

Kacerovský, M., Pavlovský, M., Tošner, J., 2009, Preterm Premature Rupture Of The Membranes And Genital Mycoplasmas, ACTA MEDICA (Hradec Králové) 52(3):117-120, dari: https://www.ncbi.nlm.nih.gov/pubmed/20073423 [10 Desember 2017]

Khumaira, M, 2012, Ilmu Kebidanan, Citra Pustaka Yogyakarta, Yogyakarta Kumar, V, Cotran, R. A, Robbins, S. L, 2011, Buku Ajar Patologi, EGC, Jakarta Kusuma,J,2013,Matrix Metalloproteinase (MMP) dan Ketuban Pecah Dini, dari: http://id.portalgaruda.org/?ref=browse \&mod=viewarticle \&article $=326208$ [10 Mei 2018]

Lapau, B, 2015, Metodologi Penelitian Kebidanan, Yayasan Pustaka Obor Indonesia, Jakarta.

Lockhart, A. \& Saputra, L, 2014, Asuhan Kebidanan Patologi, Binarupa Aksara, Tangerang

Maria,A,\& Sari 2016, Hubungan Usia Kehamilan dan Paritas Ibu Bersalin Dengan Kejadian Ketuban Pecah Dini, JURNAL VOKASI KESEHATAN Vol. II, 214-220, dari: http://ejournal.poltekkespontianak.ac.id/index.php/JVK/article/view/48 [10 Mei 2018] 
Martini, F, H, \& Nath, J, L, 2009, Fundamentals of Anatomy \& Physiology, PEARSON Benjamin Cummings, USA.

Nakubulwa, S. et al, 2015, Genital infections and risk of premature rupture of membranes in Mulago Hospital,Uganda: a case control study, BMC Res Notes, $8: 573$, dari: https://www.ncbi.nlm.nih.gov/pmc/articles/PMc4608222/ [2 Desember 2017]

Norwitz, E.R. \& Schorge, J.O. 2008, At a Glance Obstetri \& Ginekologi, EMS, Jakarta

Notoatmojo, S, 2010, Metodologi Penelitian Kesehatan, Rineka Cipta, Jakarta

Nugroho, T, 2012, Patologi Kebidanan, Nuha Medika, Jakarta

Permono,B. et al, 2012, Buku Ajar Hematologi-Onkologi Anak: cetakan ketiga, Badan Penerbit IDAI

Permono, B. et al, 2012, Buku Ajar Hematologi-Onkologi Anak: cetakan keempat, Badan Penerbit IDAI.

Pranoto, I, 2012, Patologi Kebidanan, Fitramaya, Yogyakarta

Prawirohardjo, S, 2010, Ilmu Kebidanan, Bina Pustaka Sarwono Prawirohardjo, Jakarta

Profil Kesehatan 2015 Provinsi Kalimantan Tengah, dari: http://www.depkes.go.id/resources/download/profil/PROFIL_KES_PROVI NSI_2015/21_KALTENG_2015.pdf [4 Oktober 2017]

Rahayu, B, \& Sari, A, N, 2017, Studi Deskriptif Penyebab Kejadian Ketuban Pecah Dini (KPD) pada Ibu Bersalin, INDONESIAN JOURNAL OF NURSING AND MIDWIFERY, dari: http://ejournal.almaata.ac.id/index.php/JNKI/article/view/450 [10 Mei 2018]

Rekam Medis BLUD Rumah Sakit dr. Doris Sylvanus (database), Dinas Kesehatan Provinsi Kalimantan Tengah, 2017

Ross, M, G, 2011. Preterm Labor, dari: https://emedicine.medscape.com/article/260998-overview[17 Februri 2018]

Sherwood, L, 2012, Fisiologi Manusia, Penerbit Buku Kedokteran (EGC), Jakarta

Sulistyaningsih, 2011, Metodologi Penelitian Kebidanan, Graha Ilmu, Yogyakarta

Wulandari, E, 2016, Analisis Faktor Resiko Terhadap Kejadian Ketuban Pecah Dini Pada Ibu Melahirkan Di RSUD Tugurejo Semarang, dari http:/ /repository.unimus.ac.id [26 Mei 2018] 